\title{
Data report: permeability, compressibility, and microstructure of resedimented mudstone from IODP Expedition 322, Site C0011'
}

\author{
Julia Schneider Reece, ${ }^{2}$ Peter B. Flemings, ${ }^{3}$ and John T. Germaine ${ }^{4}$
}

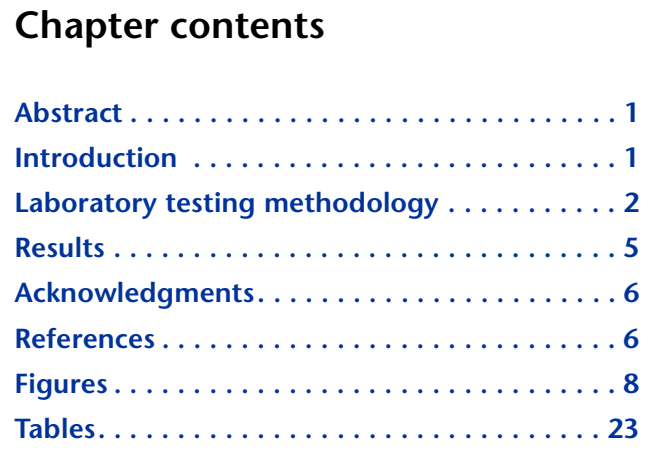

${ }^{1}$ Reece, J.S., Flemings, P.B., and Germaine, J.T., 2013. Data report: permeability, compressibility, and microstructure of resedimented mudstone from IODP Expedition 322, Site C0011. In Saito, S. Underwood, M.B., Kubo, Y., and the Expedition 322 Scientists, Proc. IODP, 322: Tokyo (Integrated Ocean Drilling Program Management International, Inc.). doi:10.2204/iodp.proc.322.205.2013

${ }^{2}$ Bureau of Economic Geology, University of Texas at Austin, University Station, Box X, Austin TX

78713, USA. Correspondence author: jschneider@ utexas.edu

${ }^{3}$ John A. and Katherine G. Jackson School of Geosciences, University of Texas at Austin, 1 University Station C1160, Austin TX 78712, USA.

${ }^{4}$ Department of Civil and Environmental Engineering, Massachusetts Institute of Technology, Cambridge MA 02139, USA.

\section{Abstract}

We conducted Atterberg limits measurements, particle size analyses, and uniaxial constant rate of strain consolidation experiments on six sediment samples, which were prepared in the laboratory using resedimentation, to characterize the material and analyze compression and flow behavior. We performed all experiments in the GeoMechanics Laboratory at the University of Texas at Austin (Texas, USA). The six samples are sediment mixtures composed of varying proportions of Nankai silty claystone, which was homogenized from a large number of discrete samples that were collected during Integrated Ocean Drilling Program (IODP) Expedition 322 from Site C0011, and silt-size silica from US Silica. The particle size distributions vary from $56 \%$ to $32 \%$ clay-size particles with no sand present. The compression index $\left(C_{c}\right)$ systematically decreases with decreasing clay-size fraction. For clay-rich mixtures, $C_{c}$ also significantly decreases with vertical effective stress $\left(\sigma_{\mathrm{v}}^{\prime}\right)$, whereas silt-rich mixtures show constant $C_{\mathrm{c}}$. Vertical intrinsic permeability decreases with increasing $\sigma^{\prime}$ and varies $\log$ linearly with porosity. Slopes of this log-linear relationship vary between 11.8 and 9.8 for mixtures from 56\% clay to 32\% clay. At a given porosity, vertical permeability increases by two orders of magnitude for clay contents ranging from $56 \%$ to $32 \%$.

\section{Introduction}

Integrated Ocean Drilling Program (IODP) Expedition 322 is part of the Nankai Trough Seismogenic Zone Experiment (NanTroSEIZE) project and aimed at understanding the initial presubduction conditions because the downdip evolution of those initial properties is what ultimately changes slip behavior along the plate interface from aseismic to seismic (Vrolijk, 1990; Hyndman et al., 1997; Moore and Saffer, 2001; Tobin and Kinoshita, 2006). Expedition 322 sampled and logged the incoming sedimentary strata and uppermost igneous basement of the Shikoku Basin, seaward of the Nankai Trough (southwestern Japan) prior to their arrival and burial at the Nankai subduction front (Saito et al., 2009; Underwood et al., 2010). Two sites were drilled: IODP Site C0011 on the northwest flank of the bathymetric high called Kashinosaki Knoll and IODP Site C0012 near the crest of the seamount (Fig. F1). Here we analyze samples from Site C0011. 
During the early-middle Miocene the Shikoku Basin formed as part of the Philippine Sea plate (Okino et al., 1994; Kobayashi et al., 1995), which is currently moving toward the northwest beneath the Eurasian plate, roughly orthogonal to the axis of the Nankai Trough, at a rate of $\sim 4-6 \mathrm{~cm} / \mathrm{y}$ (Seno et al., 1993; Miyazaki and Heki, 2001) (Fig. F1). Deposits within the Shikoku Basin and the overlying Quaternary trench wedge are actively accreting at the deformation front (Tobin et al., 2009).

At Site C0011, logging-while-drilling and measurement-while-drilling data were collected at the end of IODP Expedition 319 in Hole C0011A, whereas a 536 $m$ thick succession was cored in Hole C0011B during Expedition 322 starting at 340 meters below seafloor (mbsf). The age at the bottom of the cored succession is poorly constrained within the range of middle Miocene ( 14.0 Ma) (Underwood et al., 2009). The igneous basement lies at 1050 mbsf.

Understanding compression and permeability behavior as well as overpressure and fluid flow in mudstone is critical for the identification and exploration of petroleum reserves, for any basin modeling studies, and for evaluating the stability of continental slopes. This study benefits NanTroSEIZE by understanding how porosity, permeability, and compressibility of mudstones in their initial presubduction conditions evolve over large effective stress ranges and for varying compositions, which is important for several applications: (1) pore pressure prediction in accretionary prisms, (2) accretionary wedge geometry and morphology, and (3) larger scale deformation and fluid flow in the forearc of convergent margins.

We used a method called resedimentation to prepare homogeneous and undisturbed samples in the laboratory under controlled stress conditions. The key advantages of resedimented over intact core samples are homogeneity, no disturbance, and controlled stress history. Thus, resedimentation is ideal for geotechnical experimentation in situations where drilling-induced disturbance is present and where systematic studies are being performed to understand fundamental sediment behavior. The samples are mixtures of varying proportions of silty claystone, mostly from the lower Shikoku Basin hemipelagic facies from depths between 580.4 and 865.9 mbsf in Hole C0011B, and commercially available silt-size silica. We then conducted Atterberg limits measurements, particle size analyses, and constant rate of strain (CRS) consolidation tests and took scanning electron microscope (SEM) images in order to understand the compositional influence on deformation, flow behavior, and microstructure such as the change in packing and particle alignment.

\section{Laboratory testing methodology}

\section{Sample handling and preparation}

Bulk material from Cores 322-C0011B-30R through 58R, corresponding to 580.4-865.9 mbsf and lithologic Units III and IV, was collected in 10 bags with $24.9 \mathrm{~kg}$ in total and shipped to the University of Texas (UT) at Austin (Texas, USA) laboratory. Table T1 lists the mass, core, depth, and lithologic unit of each bag of collected material. About one half of the total mass is from lithologic Unit III and the other half is from lithologic Unit IV. We then air-dried the bulk material and ground it in a ball grinder to destroy aggregates in order to start resedimentation with an unstructured, dispersed fabric. The entire ground material was sieved through a \#60 mesh $(0.251 \mathrm{~mm})$ and then homogenized to a single batch. We added silt-size silica (MIN U SIL 40) from US Silica to the baseline batch of Nankai silty claystone in the following dry mass proportions of silty claystone to silica: 100:00, 88:12, 76:24, 64:36, 52:48, and 40:60. The silt we used is a crystalline, fine, ground, poorly sorted (well graded) silica. The range of particle sizes for the silica extends from 63 to $0.7 \mu \mathrm{m}$. The coefficients of uniformity and curvature, often used in geotechnical engineering, are 7 and 2 , respectively.

\section{Sample mineralogy}

The mineralogic composition of the Nankai silty claystone was measured by Macaulay Scientific Consulting LTD in Aberdeen, UK. Both whole rock and $<2 \mu \mathrm{m}$ clay fraction analyses were performed by Xray powder diffraction (XRPD). The bulk samples were dried at $105^{\circ} \mathrm{C}$, wet ground (in ethanol) in a McCrone mill, and spray dried to produce random powders. The XRPD patterns were recorded from $2^{\circ}$ to $75^{\circ} 2 \theta$ using cobalt $\mathrm{K} \alpha$ radiation. Quantitative analysis was done by a normalized full pattern reference intensity ratio method (Hillier, 2000). The XRPD patterns were referenced to patterns from the International Centre for Diffraction Database (ICDD). Expanded uncertainty using a coverage of 2 (i.e., $95 \%$ confidence, given by $\pm X^{0.35}$, where $X=$ concentration in weight percent [e.g., $30 \mathrm{wt} \% \pm$ 3.3]). There may also be uncertainty for phases at the trace level $(<1 \%)$ as to whether or not the phase is truly present in the sample. The bulk sample contains quartz (24 wt\%), feldspar (16 wt\%), and clay minerals (59 wt\%) with lesser amounts of calcite, pyrite, and halite (Table T2; Fig. F2A).

The clay fraction $<2 \mu \mathrm{m}$ was obtained by timed sedimentation. It was prepared as oriented mounts using the filter peel transfer technique and scanned from $2^{\circ}$ to $45^{\circ} 2 \theta$ in the air-dried state, after glycolation, 
and after heating to $300^{\circ} \mathrm{C}$ for $1 \mathrm{~h}$. Identified clay minerals were quantified using a mineral intensity factor approach based on calculated XRPD patterns. Uncertainty for clay minerals in amounts $>10 \mathrm{wt} \%$ is estimated as better than $\pm 5 \mathrm{wt} \%$ at the $95 \%$ confidence level. The clay-size fraction is dominated by smectite (85 wt $\%)$ with lesser amounts of illite (11 $\mathrm{wt} \%)$, chlorite $(3 \mathrm{wt} \%)$, and kaolinite $(1 \mathrm{wt} \%)$ (Table T2; Fig. F2B). The expandability of the illite/smectite (I/S) mixed-layer clay was estimated from the data in table 8.3 in Moore and Reynolds (1997), which have been tabulated from calculated diffractograms for each specific composition, and is $\sim 80 \%$.

The bulk mineralogic composition of the homogenized, resedimented Nankai silty claystone is in agreement with the shipboard X-ray diffraction (XRD) measurements of bulk powders (Underwood et al., 2009). About $24 \mathrm{wt} \%$ quartz and $16 \mathrm{wt} \%$ feldspar were measured in the Nankai silty claystone, whereas the shipboard analyses measured on average $18 \mathrm{wt} \%$ and $11 \mathrm{wt} \%$, respectively (Underwood et al., 2009). These slightly increased fractions of quartz and feldspar in the Nankai silty claystone are consistent with a $10 \mathrm{wt} \%$ decrease in total clay minerals compared to the shipboard samples (Underwood et al., 2009, Underwood and Guo, in press). The abundance of smectite in the bulk Nankai silty claystone is $45 \mathrm{wt} \%$, which is on average equal to the smectite abundance in the bulk mudstone at Site C0011 (Underwood and Guo, in press).

The abundances of clay minerals in the clay-size fraction of the homogenized, resedimented Nankai silty claystone are consistent with XRD measurements on the clay-size fraction of the mudstone at Site C0011 as presented by Underwood and Guo (in press). Smectite is the dominant clay-size mineral. However, its abundance is higher in the Nankai silty claystone (85 wt\%) than in the mudstone, where smectite averages $59 \mathrm{wt} \%$ in Unit III and $68 \mathrm{wt} \%$ in Unit IV (Underwood and Guo, in press). Similarly, values of illite (11 wt \%) and chlorite + kaolinite ( $4 \mathrm{wt} \%)$ for the Nankai silty claystone are lower than for the mudstone, where illite averages 27 and $20 \mathrm{wt} \%$, and chlorite + kaolinite average 4 and $7 \mathrm{wt} \%$ for Units III and IV, respectively (Underwood and Guo, in press). However, it has to be noted that these relative mineral abundances in the clay-size fraction of the mudstone also include clay-size quartz as opposed to only clay minerals in the Nankai silty claystone. The $80 \%$ I/S expandability of the Nankai silty claystone is consistent with an average I/S expandability of $77 \%$ of the mudstone (Underwood and Guo, in press).

\section{Atterberg limits}

We measured Atterberg limits such as the liquid limit (LL), plastic limit (PL), and plasticity index (PI) on the mudstone mixtures in accordance to American Society for Testing and Materials (ASTM) Standard D4318-05 (ASTM International, 2005). Atterberg limits are used to characterize the fine-grained fraction of soils and, together with other soil properties, to correlate with engineering behavior such as compressibility, hydraulic conductivity, intrinsic permeability, and shear strength, for example. Liquid and plastic limits are water contents that separate different consistency states from each other. We performed the multipoint LL method (ASTM International, 2005) using a hand-operated LL device, also called a Casagrande cup. We determined the PL by the hand method (ASTM International, 2005). PI is the range of water content over which the soil behaves plastically, or numerically, the difference between LL and PL.

\section{Particle size analysis}

After consolidation to $21 \mathrm{MPa}$, we ground all six samples with a mortar and pestle and determined the particle size distributions using the hydrometer method in general accordance with ASTM D422-63 guidelines (ASTM International, 2007) and Sawyer et al. (2008). Two hydrometer tests performed on the bulk Nankai silty claystone before compression produced almost identical particle size distribution curves than the hydrometer test performed after compression, indicating no mechanical effects on the particle size distribution. Therefore, we only performed hydrometer tests on the exact same specimens that were resedimented and uniaxially consolidated. The hydrometer method uses a suspension of sediment and water, which is thoroughly mixed, after which particles settle out of the water column according to Stoke's law. We added $5 \mathrm{~g}$ of dispersing agent (sodium hexametaphosphate) to each suspension of $1000 \mathrm{~mL}$. A hydrometer measures the specific gravity $\left(G_{s}\right)$ of the suspension at known depths below the air-suspension interface and at known times. From the hydrometer tests, we obtain the particle diameter at a specific time and depth and the percentage of the original sample mass still left in suspension.

\section{Resedimentation}

We prepared six sediment samples in the laboratory using the resedimentation method (Santagata and 
Kang, 2007; Sheahan, 1991; Schneider, 2011) that was developed at the Massachusetts Institute of Technology and simulates natural sedimentation under controlled stress conditions. The dried, ground, and homogenized Nankai silty claystone was mixed at a water content of $105 \%$ with a solution of deionized water and $26 \mathrm{~g} / \mathrm{L}$ sea salt to form a stable slurry (i.e., no particles segregated). We accounted for the residual salt in the Nankai silty claystone assuming an in situ salt content of $35 \mathrm{~g} / \mathrm{L}$ and in situ water content of $27 \%$ based on moisture and density (MAD) measurements averaged over the depth range of 580.4-865.9 mbsf. For the Nankai silty claystonesilica mixtures, these values for water and salt content only applied to the claystone fraction. The silica fraction was just moistened with deionized water at a water content of 33\% to avoid attracting any of the water that was reserved for the claystone. Then the moistened silica was mixed in with the Nankai silty claystone.

After homogenizing the slurry with a spatula for at least $20 \mathrm{~min}$, the slurry was de-aired using a vacuum pump to eliminate any air bubbles. Then we poured the slurry into a consolidometer with an inside diameter of $6.9 \mathrm{~cm}$. Below and on top of the slurry were a porous stone and filter paper allowing pore fluids to drain in both directions but preventing fines from being washed out. The initial height of all samples varied between 11.5 and $13.6 \mathrm{~cm}$.

We incrementally loaded the slurry, doubling the mass on the slurry every time, to a maximum vertical effective stress of $100 \mathrm{kPa}$. A linear position transducer, which at the time of measurement could not be mounted onto the system until the beginning of the fifth stress increment due to weight restrictions, monitored vertical displacement throughout the resedimentation experiment. The last weight increment was left on the slurry until the sediment reached secondary consolidation.

After unloading the sample to an overconsolidation ratio (OCR) (maximum past effective stress of 100 $\mathrm{kPa}$ divided by the current effective stress of $25 \mathrm{kPa}$ ) of 4 , we carefully and slowly extruded the samples. The final height of all samples varied between 8.2 and $9.2 \mathrm{~cm}$. A small slice of material was cut off for determination of void ratio at the end of the resedimentation experiment using the wet and dry mass technique. This void ratio value was used, along with the uniaxial deformation data, to back out void ratios at any vertical effective stress assuming that the axial strain is equal to the volumetric strain. The remaining samples each yielded two specimens for consolidation testing, of which only one was tested and shown here.

\section{Index properties}

We measured the water content by oven-drying the sample at $105^{\circ} \mathrm{C}$. Water content is calculated by taking the difference in the mass of the sample before and after oven-drying and dividing this difference by the oven-dried mass. We did not correct for salt content in the pore water when calculating water content. We reported the water content of the test specimen $\left(w_{n}\right)$ for each experiment (Table T3). We also provided the initial void ratio $\left(e_{i}\right)$ for each specimen (Table T3). Void ratio (e) is defined as the volume of voids divided by the volume of solids and is nonlinearly related to porosity $(n)$ :

$$
e=n /[1-n] .
$$

From the water content and initial void ratio we calculated the initial saturation $\left(S_{\mathrm{i}}\right)$ for each specimen (Table T3):

$$
S_{\mathrm{i}}=w_{\mathrm{n}} G_{\mathrm{s}} / e_{\mathrm{i}} .
$$

Specific gravity $\left(G_{s}\right)$ of the Nankai silty claystone was derived from MAD measurements during Expedition 322 on board the D/V Chikyu (Underwood et al., 2009). Averaging MAD measurements over the sampled depth range (586.8-774.69 mbsf) yielded a grain density of $2680 \mathrm{~kg} / \mathrm{m}^{3}$ for the Nankai silty claystone. For the other five sediment mixtures, we linearly interpolated between both end-members assuming a grain density of $2650 \mathrm{~kg} / \mathrm{m}^{3}$ for the silt-size silica.

\section{Constant rate of strain consolidation testing}

After resedimenting the six sediment mixtures composed of varying proportions of Nankai silty claystone from Site C0011 and silt-size silica, we conducted CRS consolidation tests according to ASTM D4186-06 guidelines (ASTM International, 2006). We used a 10,000 lb load capacity load frame, a softwarecontrolled pump, and pressure transducers rated to 300 psi. All components were manufactured by GeoTac. The temperature in the UT laboratory was controlled to a constant $23.9^{\circ} \mathrm{C}\left( \pm 0.5^{\circ} \mathrm{C}\right)$. The specimens were trimmed into a steel ring with a diameter of $4.99 \mathrm{~cm}$ using a trimming jig, wire saw, and sharpedge spatula. Once the specimen was in the ring, a wire-saw, razor blade, and recess tool were used to smooth the top and bottom of the specimen and to ensure consistent specimen dimensions. The initial height $\left(\mathrm{H}_{0}\right)$ was $1.73 \mathrm{~cm}$. We flushed all lines with deionized water and applied a constant backpressure of $386 \mathrm{kPa}$ for at least $12 \mathrm{~h}$ to ensure full saturation. 
The interaction between deionized water in the chamber and salt water in the specimen with a high amount of swelling clays most likely caused the low saturations (Table T3).

The specimens, laterally confined in the steel ring, were consolidated at a constant rate of strain (i.e., uniaxial strain). The strain rate $(d \varepsilon / d t)$ for all six specimens varied between $0.2 \% / \mathrm{h}$ and $1.05 \% / \mathrm{h}$, increasing with increasing silica content. These strain rates were not adjusted during the test, yet they ensured pore pressure ratios (ratio of excess base pore pressure to total axial stress) to be smaller than 0.1. The top of the specimen was open to the cell pressure $\left(u_{c}\right)$, whereas the bottom was undrained. During the consolidation test we continuously monitored specimen height $(H)$, total axial stress $\left(\sigma_{v}\right)$, and base pore pressure $(u)$. Experiments were run to a maximum vertical effective stress of $21 \mathrm{MPa}$, where stresses were held for $6 \mathrm{~h}$ to allow excess pore pressure to dissipate. Specimens were then unloaded to an OCR of 4 .

We computed axial strain $(\varepsilon)$, base excess pore pressure $(\Delta u)$, average vertical effective stress $\left(\sigma_{v}^{\prime}\right)$, hydraulic conductivity $(K)$, intrinsic permeability $(k)$, coefficient of volume compressibility $\left(m_{\mathrm{v}}\right)$, and coefficient of consolidation $\left(C_{\mathrm{v}}\right)$ as follows in accordance with ASTM Standard D4186-06 (ASTM International, 2006):

$$
\begin{gathered}
\varepsilon=\Delta H / \mathrm{H}_{0}, \\
\Delta u=u-u_{\mathrm{c}}, \\
\sigma_{\mathrm{v}}^{\prime}=\sigma_{\mathrm{v}}-u_{\mathrm{c}}-2 / 3 \Delta u, \\
K=d \varepsilon / d t H \mathrm{H}_{0} \gamma_{\mathrm{w}} / 2 \Delta u, \\
k=K \mu_{\mathrm{w}} / \gamma_{\mathrm{w}}, \\
m_{\mathrm{v}}=\Delta \varepsilon / \Delta \sigma_{\mathrm{v}}^{\prime},
\end{gathered}
$$

and

$$
C_{\mathrm{v}}=K / m_{\mathrm{v}} \gamma_{\mathrm{w}}
$$

where displacements were measured with linear position transducers. Variable definitions for all equations are in Table T4. In Figures F6-F11 we report strain as a percentage.

The calculation of intrinsic permeability from hydraulic conductivity requires knowledge of fluid properties. We used a viscosity of $0.001002 \mathrm{~Pa} \cdot \mathrm{s}$ for a temperature of $20^{\circ} \mathrm{C}$ and a unit weight of water of $10042.368 \mathrm{~N} / \mathrm{m}^{3}$, assuming a fluid density of $1024 \mathrm{~kg} / \mathrm{m}^{3}$ and an acceleration due to gravity of $9.81 \mathrm{~m} / \mathrm{s}^{2}$. We computed compression index $\left(C_{\mathrm{c}}\right)$, which is the slope of the virgin consolidation line, from the change in specimen void ratio $(\Delta e)$ with vertical effective stress $\left(\sigma_{v}^{\prime}\right)$ :

$$
C_{\mathrm{c}}=\Delta e / \Delta \log \left(\sigma_{\mathrm{v}}^{\prime}\right)
$$

Maximum preconsolidation stress $\left(\sigma_{p c}^{\prime}\right)$ of all specimens is $100 \mathrm{kPa}$, equal to the maximum vertical effective stress the slurry was preloaded to during resedimentation.

\section{SEM imaging}

SEM images, both backscattered (BSE) and secondary (SE) images, were taken on a field-emission SEM. The samples were prepared using an argon-ion beam milling technique (Loucks et al., 2009), which avoids mechanical polishing and instead produces surfaces with only minor topographic variations using accelerated argon ions. BSE and SE images were taken at three different magnifications $(1,000 \times, 14,000 \times$, and $60,000 \times$ ) after consolidation of sediment mixtures to a maximum vertical effective stress of $21 \mathrm{MPa}$. Images represent a vertical cross section of the sample (perpendicular to bedding) and are oriented so that the vertical stress was applied from the top of the image.

\section{Results Atterberg limits}

Atterberg limits results on the Nankai silty claystone-silica mixtures are shown in Table T5 and Figure F3. The LL, PL, and PI of the Nankai silty claystone are 68\%, 29\%, and 39\%, respectively. Because LL $>50 \%$, the Nankai silty claystone is classified as a high-plasticity soil. With decreasing clay fraction, LL, PL, and PI decrease (Table T5; Fig. F4). We performed two measurements for the Nankai silty claystone: one on air-dried material and one on ovendried material. LL is significantly affected by ovendrying; however, PL is not. LL measured on the airdried bulk material is $8 \%$ higher than LL measured on the oven-dried material. This discrepancy most likely results from the loss of interlayer water from smectite during oven-drying, which perturbs values of water content and should be accounted for in any Atterberg limits correlations.

\section{Particle size analysis}

The clay-size fractions $(<2 \mu \mathrm{m})$ by mass are $56 \%$, $50 \%, 48 \%, 41 \%, 36 \%$, and $32 \%$ for mixtures with $100 \%, 88 \%, 76 \%, 64 \%, 52 \%$, and $40 \%$ Nankai silty claystone and silica as the remainder (Table T6; Fig. F5). Thus, the specimens fall into the categories silty 
clay and clayey silt. Data sheets and curves similar to Figure F5 for each sample are available in PARTSIZE in "Supplementary material." Sand, silt, and clay percentages are given in Table $\mathbf{T} 6$.

\section{Resedimentation}

All six compression curves during resedimentation experiments are shown in Figure F6 (Table T7). Each data point represents the void ratio and vertical effective stress at the end of a stress increment. The first digitally measured void ratio (at $2.6 \mathrm{kPa}$ ) systematically decreases from 2.50 to 1.57 for specimens with $100 \%$ to $40 \%$ Nankai silty claystone. The compression index $\left(C_{c}\right)$ decreases from 0.63 to 0.37 for specimens with $100 \%$ to $40 \%$ Nankai silty claystone, showing that the samples become stiffer the more silica they contain.

\section{Consolidation testing}

We conducted CRS tests on the Nankai silty claystone-silica mixtures. Table T3 summarizes details of each CRS test. Figures F7, F8, F9, F10, F11, and F12 show the consolidation curves in both $\varepsilon-\log \left(\sigma_{v}^{\prime}\right)$ and $e-\log \left(\sigma_{v}^{\prime}\right)$, normalized excess pore pressure $\left(\Delta u / \sigma_{v}\right)$, hydraulic conductivity $(K)$, coefficient of consolidation $\left(C_{v}\right)$, and intrinsic permeability $(k)$ for each CRS test. The CRS data sheets are in CRS in "Supplementary material."

Because all six CRS tests were performed on homogeneous samples prepared in the laboratory under controlled conditions and contain only Nankai silty claystone and silt-size silica, we can compare the results in order to analyze the compositional influence on the compression and flow behavior. The initial void ratio $\left(e_{\mathrm{i}}\right)$ decreases from 1.63 to 0.98 for samples with $100 \%$ to $40 \%$ Nankai silty claystone. The compression index $\left(C_{c}\right)$, which refers to the slope of the normally consolidated portion of the compression curve in $e-\log \left(\sigma_{\mathrm{v}}^{\prime}\right)$ space, is determined over the vertical effective stress range between 0.2 and $5 \mathrm{MPa}$ and ranges from 0.64 to 0.26 for samples with $100 \%$ to $40 \%$ Nankai silty claystone (Table T3). $C_{c}$ decreases with increasing vertical effective stress, particularly for the clay-rich samples. For a vertical effective stress range between 5 and $20 \mathrm{MPa}, C_{\mathrm{c}}$ varies from 0.36 to 0.24 for samples with $100 \%$ to $40 \%$ Nankai silty claystone (Table T3). The expansion index $\left(C_{\mathrm{e}}\right)$, which refers to the slope of the unloading portion of the compression curve in $e-\log \left(\sigma_{\mathrm{v}}^{\prime}\right)$ space, is determined over the vertical effective stress range between 5 and $20 \mathrm{MPa}$ and ranges from 0.056 to 0.017 for samples with $100 \%$ to $40 \%$ Nankai silty claystone.
Vertical intrinsic permeability $(k)$ varies log-linearly with porosity $\left(\log [\mathrm{k}]=\gamma n+\log \left[k_{0}\right]\right)$ and increases with decreasing clay fraction. At a given porosity of $40 \%$, the difference in permeability between mixtures with $100 \%$ and $40 \%$ Nankai silty claystone is two orders of magnitude. Values of $\gamma$ and $\log \left(k_{0}\right)$ are listed in Table T3.

The coefficient of consolidation (Equation 9) ranges from $6.1 \times 10^{-9}$ to $3.2 \times 10^{-7} \mathrm{~m}^{2} / \mathrm{s}$ for samples with $100 \%$ to $40 \%$ Nankai silty claystone. In case of tests CRS088 and CRS089, $C_{v}$ does not approach a constant value; instead, $C_{v}$ continues to decrease with increasing vertical effective stress. Thus, in those cases we report $C_{\mathrm{v}}$ at maximum vertical effective stress of $21 \mathrm{MPa}$.

\section{SEM imaging}

One BSE image at a magnification of $14,000 \times$ for each sediment mixture after consolidation to a vertical effective stress of $21 \mathrm{MPa}$ is shown in Figure F13. Additional BSE and SE images at vertical effective stresses of $21 \mathrm{MPa}$ as well as $100 \mathrm{kPa}$ are in SEM in "Supplementary material." BSE images show a strong decrease in clay particle alignment with decreasing clay fraction. Pores in the Nankai silty claystone are either elongated pores between similarly oriented clay sheets or triangular to crescent-shaped pores in folded clays, particularly in between smectites (Fig. F13A, F13B). In coarser samples large jagged pores are preserved where silt grains touch each other and form silt bridges (Fig. F13I-F13L). A gradual increase in mean pore size with decreasing clay fraction occurs.

\section{Acknowledgments}

This research used samples and data provided by the Integrated Ocean Drilling Program (IODP). Funding for this research was provided by the Consortium for Ocean Leadership through the Schlanger Ocean Drilling Fellowship received by J. Schneider Reece. Robert M. Reed prepared the SEM images. Publication authorized by the Director, Bureau of Economic Geology, The University of Texas at Austin. This IODP data report is The University of Texas at Austin Institute of Geophysics Contribution 2561.

\section{References}

ASTM International, 2005. Standard test methods for liquid limit, plastic limit, and plasticity index of soils (Standard D4318-05). In Annual Book of ASTM Standards (Vol. 04.08): West Conshohocken, PA. (Am. Soc. Testing 
Mater.). http://www.astm.org/DATABASE.CART/HISTORICAL/D4318-05.htm

ASTM International, 2006. Standard test method for onedimensional consolidation properties of saturated cohesive soils using controlled-strain loading (Standard D4186-06). In Annual Book of ASTM Standards (Vol. 04.08): Soil and Rock (I): West Conshohocken, PA (Am. Soc. Testing Mater.) http://www.astm.org/DATABASE.CART/HISTORICAL/D4186-06.htm

ASTM International, 2007. Standard test method for particle-size analysis of soils (Standard D422-63[2007]). In Annual Book of ASTM Standards (Vol. 04.08): Soil and Rock (I): West Conshohocken, PA (Am. So. Testing Mater.). doi:10.1520/D0422-63R07

Hillier, S., 2000. Accurate quantitative analysis of clay and other minerals in sandstones by XRD: comparison of a Rietveld and a reference intensity ratio (RIR) method and the importance of sample preparation. Clay Miner., 35(1):291. doi:10.1180/000985500546666

Hyndman, R.D., Yamano, M., and Oleskevich, D.A., 1997. The seismogenic zone of subduction thrust faults. Isl. Arc, 6(3):244-260. doi:10.1111/j.14401738.1997.tb00175.x

Kobayashi, K., Kasuga, S., and Okino, K., 1995. Shikoku Basin and its margins. In Taylor, B. (Ed.), Backarc Basins: Tectonics and Magmatism: New York (Plenum), 381-405.

Loucks, R.G., Reed, R.M., Ruppel, S.C., and Jarvie, D.M., 2009. Morphology, genesis, and distribution of nanometer-scale pores in siliceous mudstones of the Mississippian Barnett Shale. J. Sediment. Res., 79(12):848-861. doi:10.2110/jsr.2009.092

Miyazaki, S., and Heki, K., 2001. Crustal velocity field of southwest Japan: subduction and arc-arc collision. J. Geophys. Res., [Solid Earth], 106(B3):4305-4326. doi:10.1029/2000JB900312

Moore, D.M., and Reynolds, R.C., Jr., 1997. X-ray Diffraction and the Identification and Analysis of Clay Minerals (2nd ed.): Oxford (Oxford Univ. Press).

Moore, J.C., and Saffer, D., 2001. Updip limit of the seismogenic zone beneath the accretionary prism of southwest Japan: an effect of diagenetic to low-grade metamorphic processes and increasing effective stress. Geology, 29(2):183-186. doi:10.1130/00917613(2001)029<0183:ULOTSZ>2.0.CO;2

Okino, K., Shimakawa, Y., and Nagaoka, S., 1994. Evolution of the Shikoku Basin. J. Geomagn. Geoelectr., 46(6):463-479. doi:10.5636/jgg.46.463

Saito, S., Underwood, M.B., and Kubo, Y., 2009. NanTroSEIZE Stage 2: subduction inputs. IODP Sci. Prosp., 322. doi:10.2204/iodp.sp.322.2009

Santagata, M., and Kang, Y.I., 2007. Effects of geologic time on the initial stiffness of clays. Eng. Geol. (Amsterdam, Neth.), 89(1-2):98-111. doi:10.1016/j.enggeo.2006.09.018

Sawyer, D.E., Jacoby, R., Flemings, P., and Germaine, J.T., 2008. Data report: particle size analysis of sediments in the Ursa Basin, IODP Expedition 308 Sites U1324 and U1322, northern Gulf of Mexico. In Flemings, P.B., Behrmann, J.H., John, C.M., and the Expedition 308 Scientists, Proc. IODP, 308: College Station, TX (Integrated Ocean Drilling Program Management International, Inc.). doi:10.2204/iodp.proc.308.205.2008

Schneider, J., 2011. Compression and permeability behavior of natural mudstones [Ph.D. thesis]. Univ. Texas, Austin. http://hdl.handle.net/2152/ETD-UT-2011-124730

Seno, T., Stein, S., and Gripp, A.E., 1993. A model for the motion of the Philippine Sea plate consistent with NUVEL-1 and geological data. J. Geophys. Res., [Solid Earth], 98(B10):17941-17948. doi:10.1029/93JB00782

Sheahan, T.C., 1991. An experimental study of the timedependent undrained shear behavior of resedimented clay using automated stress path triaxial equipment [Ph.D. thesis]. MIT, Cambridge, MA. http:// dspace.mit.edu/handle/1721.1/13486

Tobin, H., Kinoshita, M., Ashi, J., Lallemant, S., Kimura, G., Screaton, E.J., Moe, K.T., Masago, H., Curewitz, D., and the Expedition 314/315/316 Scientists, 2009. NanTroSEIZE Stage 1 expeditions: introduction and synthesis of key results. In Kinoshita, M., Tobin, H., Ashi, J., Kimura, G., Lallemant, S., Screaton, E.J., Curewitz, D., Masago, H., Moe, K.T., and the Expedition 314/315/316 Scientists, Proc. IODP, 314/315/316: Washington, DC (Integrated Ocean Drilling Program Management International, Inc.). doi:10.2204/ iodp.proc.314315316.101.2009

Tobin, H.J., and Kinoshita, M., 2006. NanTroSEIZE: the IODP Nankai Trough Seismogenic Zone Experiment. Sci. Drill., 2:23-27. doi:10.2204/iodp.sd.2.06.2006

Underwood, M.B., and Guo, J., in press. Data report: clay mineral assemblages in the Shikoku Basin, NanTroSEIZE Subduction. In Saito, S., Underwood, M.B., Kubo, Y., and the Expedition 322 Scientists, Proc. IODP, 322: Tokyo (Integrated Ocean Drilling Program Management International, Inc.).

Underwood, M.B., Saito, S., Kubo, Y., and the Expedition 322 Scientists, 2009. NanTroSEIZE Stage 2: subduction inputs. IODP Prel. Rept., 322. doi:10.2204/ iodp.pr.322.2009

Underwood, M.B., Saito, S., Kubo, Y., and the IODP Expedition 322 Scientists, 2010. IODP Expedition 322 drills two sites to document inputs to the Nankai Trough Subduction Zone. Sci. Drill., 10:14-25. doi:10.2204/ iodp.sd.10.02.2010

Vrolijk, P., 1990. On the mechanical role of smectite in subduction zones. Geology, 18(8):703-707. doi:10.1130/ 0091-7613(1990)018<0703:OTMROS >2.3.CO;2

Initial receipt: 5 June 2012

Acceptance: 14 December 2012

Publication: 14 March 2013

MS 322-205 
Figure F1. Bathymetry map with Expedition 322 Site C0011 (after Underwood et al., 2009). Black line $\left(A-A^{\prime}\right)=$ seismic line from the Kumano Basin to the Kashinosaki Knoll in the Shikoku Basin, white transparent line = deformation front, arrow $=$ convergence vector between Philippine Sea plate and Japanese Islands (Eurasian plate), red star = 1944 Tonankai M 8.2 earthquake.

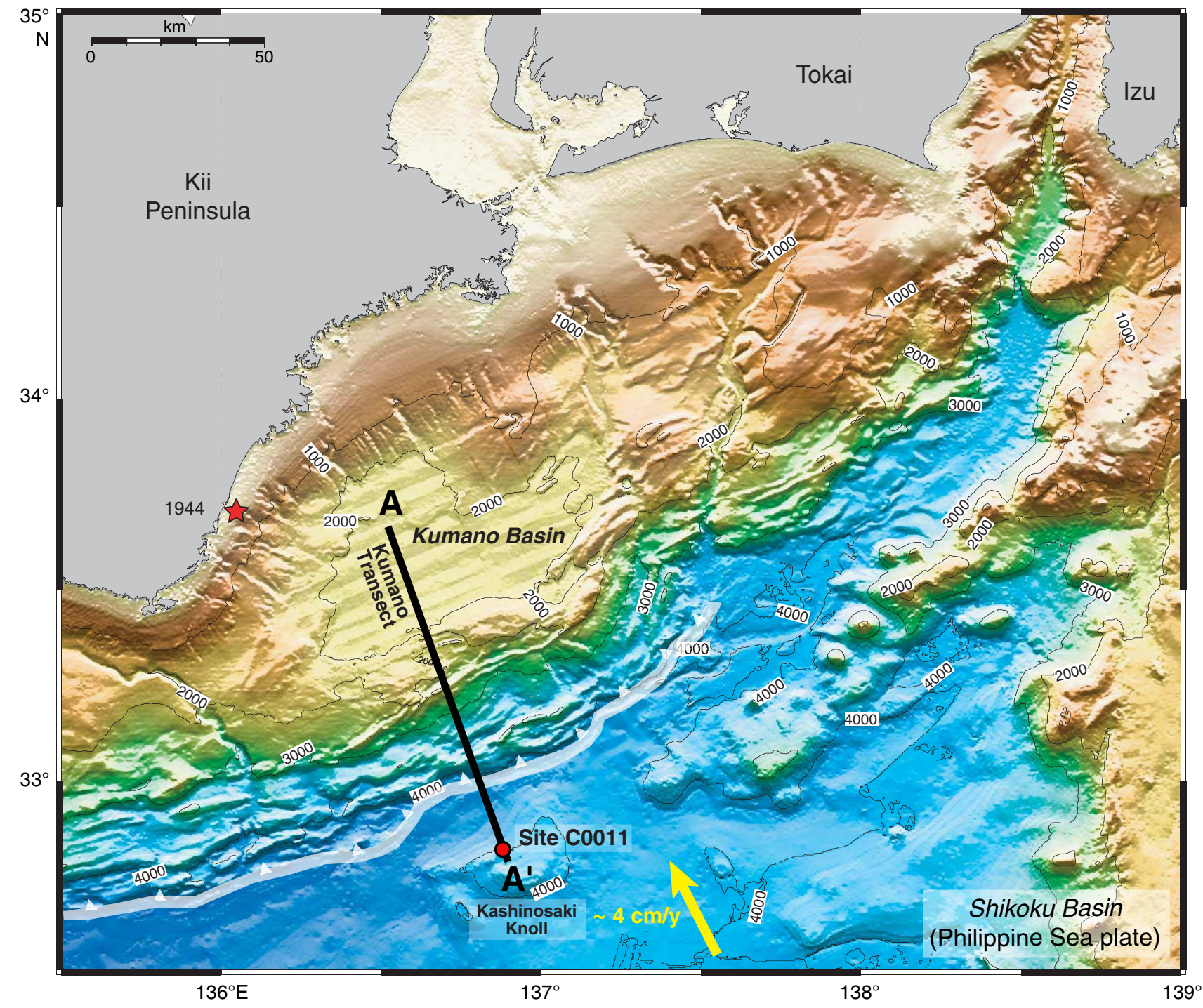


Figure F2. Mineralogy of Nankai silty claystone measured through X-ray powder diffraction by Macaulay Scientific Consulting LTD (Table T2). A. Mineralogy of whole rock determined using the reference intensity ratio method (Hillier, 2000). B. Mineralogy of clay fraction $<2 \mu \mathrm{m}$ expressed as relative weight percent.

A



B Kaolinite

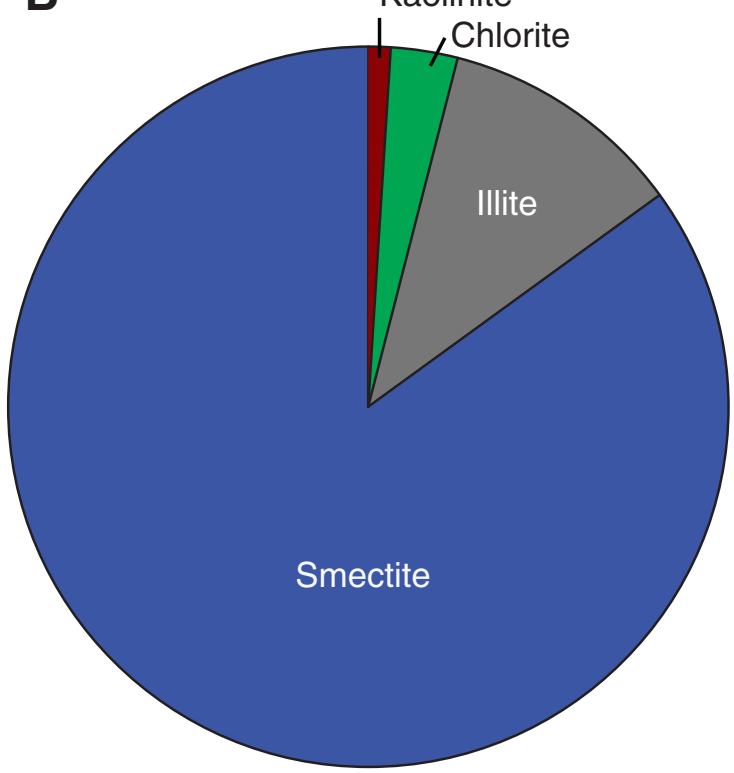


Figure F3. Plasticity chart (Table T5). Open circle $=56 \%$ clay measured on air-dried bulk material (before resedimentation), solid circle $=56 \%$ clay measured on oven-dried specimen after resedimentation/before CRS testing. Measurements of 50\%, 48\%, 41\%, 36\%, and 32\% clay samples were done on oven-dried specimens after CRS testing. U-Line is an upper boundary of expected results for natural soils. A-Line separates clay from silt.




Figure F4. Relationship between Atterberg limits and clay fraction (Table T5). LL = liquid limit, PL = plastic limit, PI = plasticity index, $\mathrm{cf}=$ clay fraction .

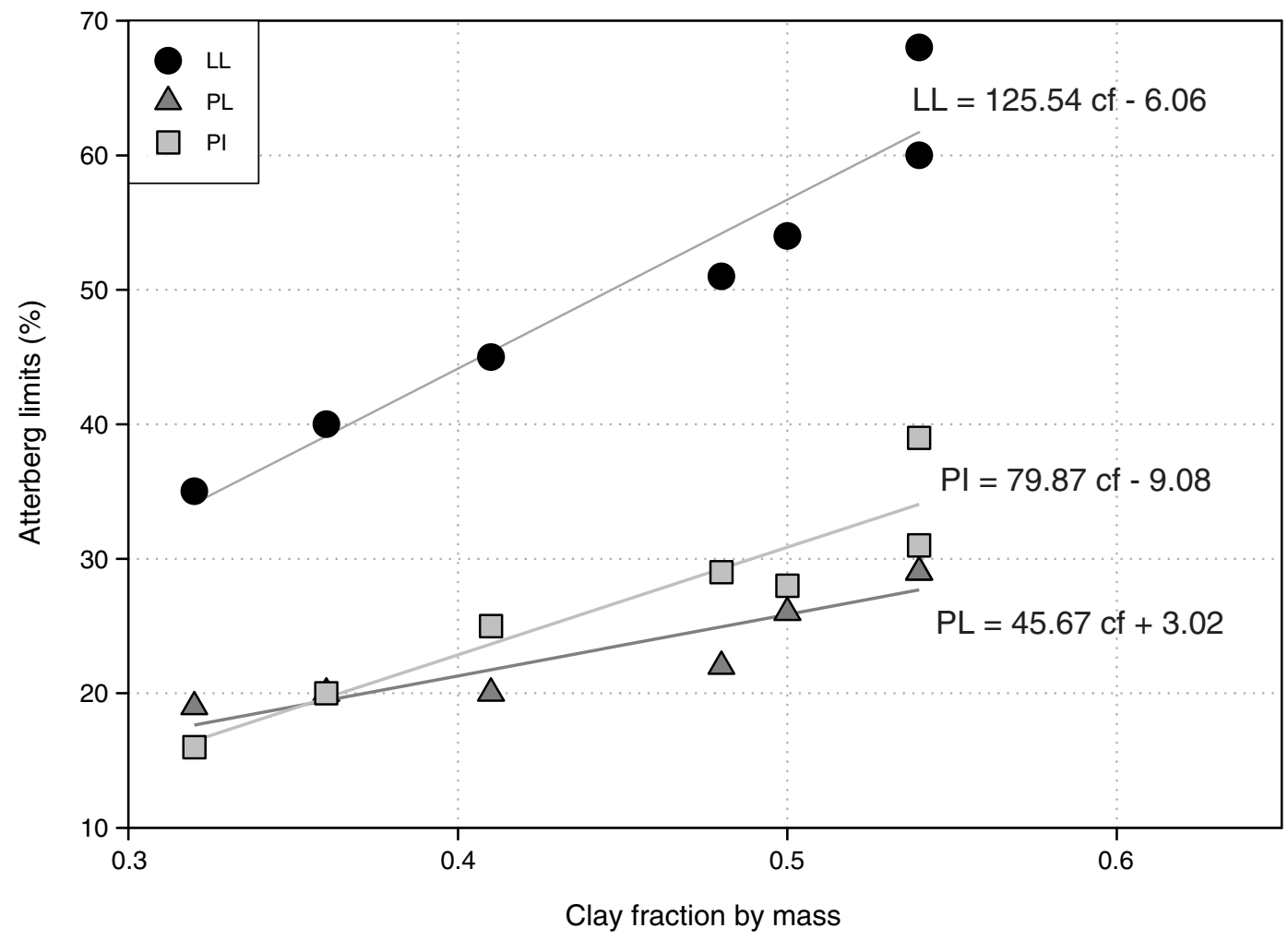


Figure F5. Particle size distribution plots on a semi-log scale (Table T6). All data points represent hydrometer readings. Sand/silt boundary is defined at $62.5 \mu \mathrm{m}$ and silt/clay boundary is defined at $2 \mu \mathrm{m}$. Black circles = $56 \%$ clay, dark blue diamonds $=50 \%$ clay, light blue squares $=48 \%$ clay, green triangles $=41 \%$ clay, red triangles $=36 \%$ clay, brown stars $=32 \%$ clay, yellow circles $=$ silt-size silica $(8 \%$ clay). Particle size distribution sheets for all experiments are in PARTSIZE in "Supplementary material."

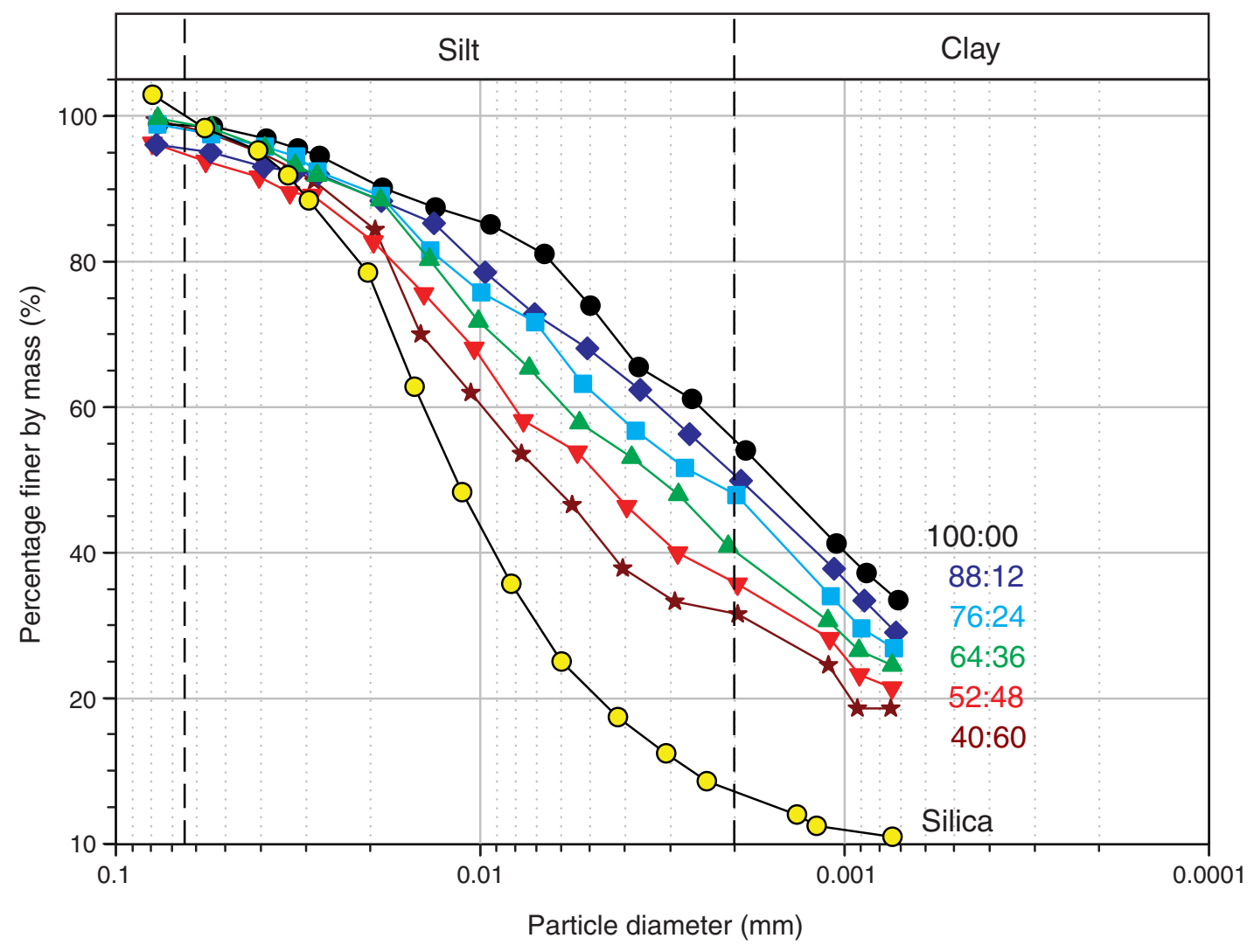


Figure F6. Compression curves during resedimentation (Table T7). Each data point represents the vertical effective stress and void ratio at the end of a stress increment. Black circles $=56 \%$ clay, dark blue diamonds $=50 \%$ clay, light blue squares $=48 \%$ clay, green triangles $=41 \%$ clay, red triangles $=36 \%$ clay, brown stars $=32 \%$ clay.

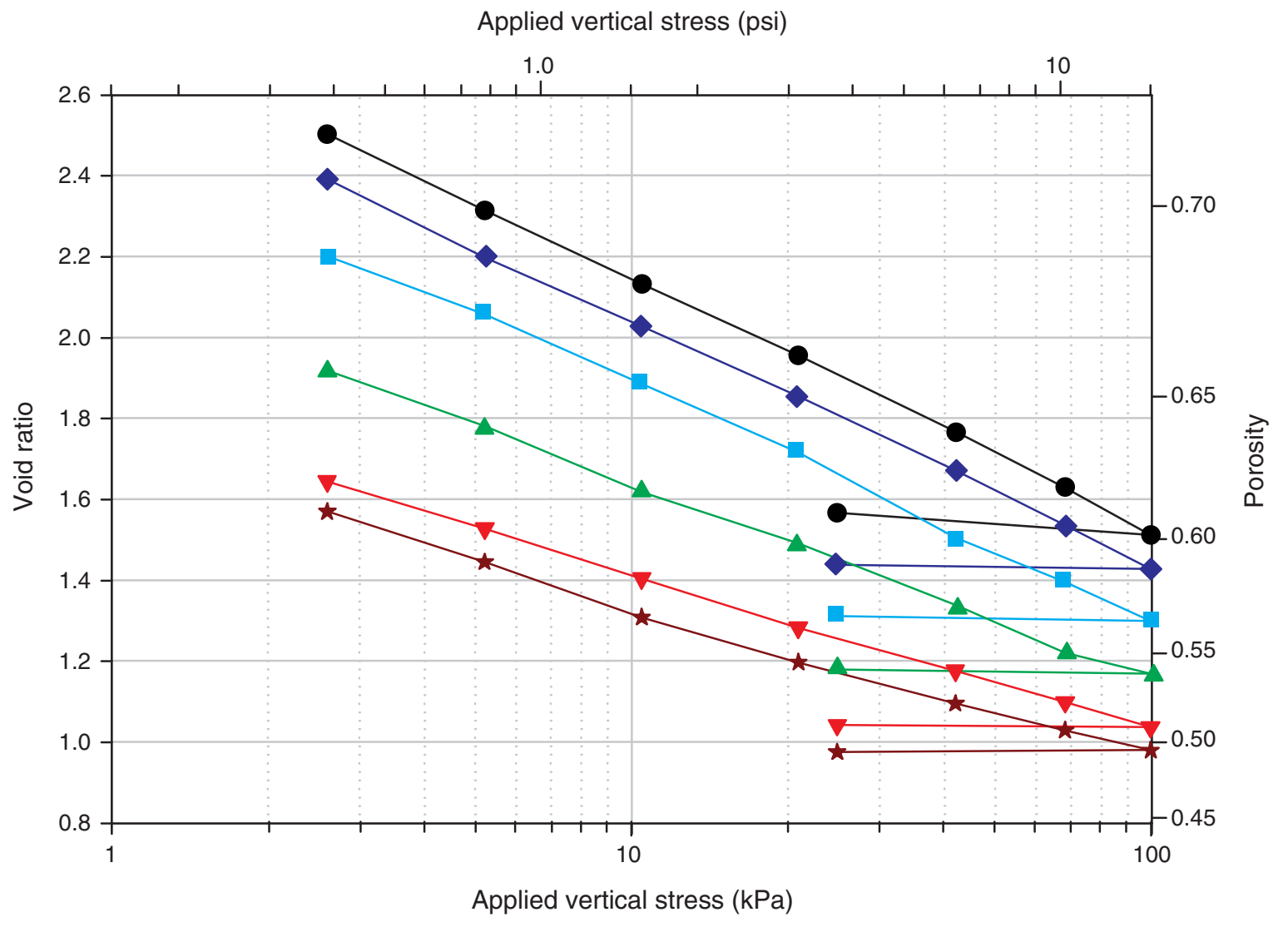


Figure F7. Experimental consolidation results for the sample with 56\% clay-size particles (100\% Nankai silty claystone and 00\% silica, CRS090). Consolidation data are in CRS in "Supplementary material."
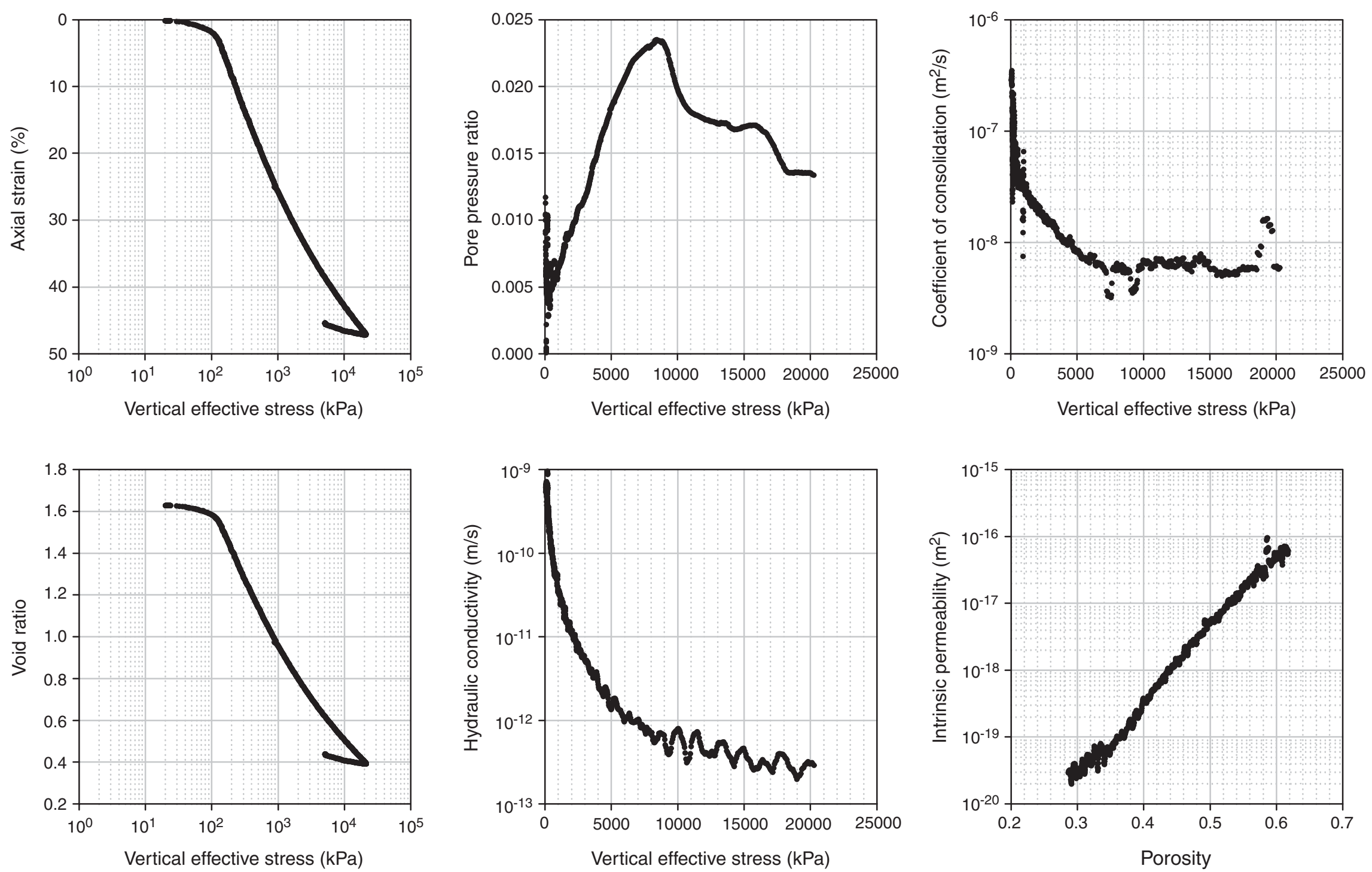
Figure F8. Experimental consolidation results for the sample with 50\% clay-size particles (88\% Nankai silty claystone and $12 \%$ silica, CRS091). Consolidation data are in CRS in "Supplementary material."

Figure F9. Experimental consolidation results for the sample with 48\% clay-size particles (76\% Nankai silty claystone and $24 \%$ silica, CRS093). Consolidation data are in CRS in "Supplementary material."
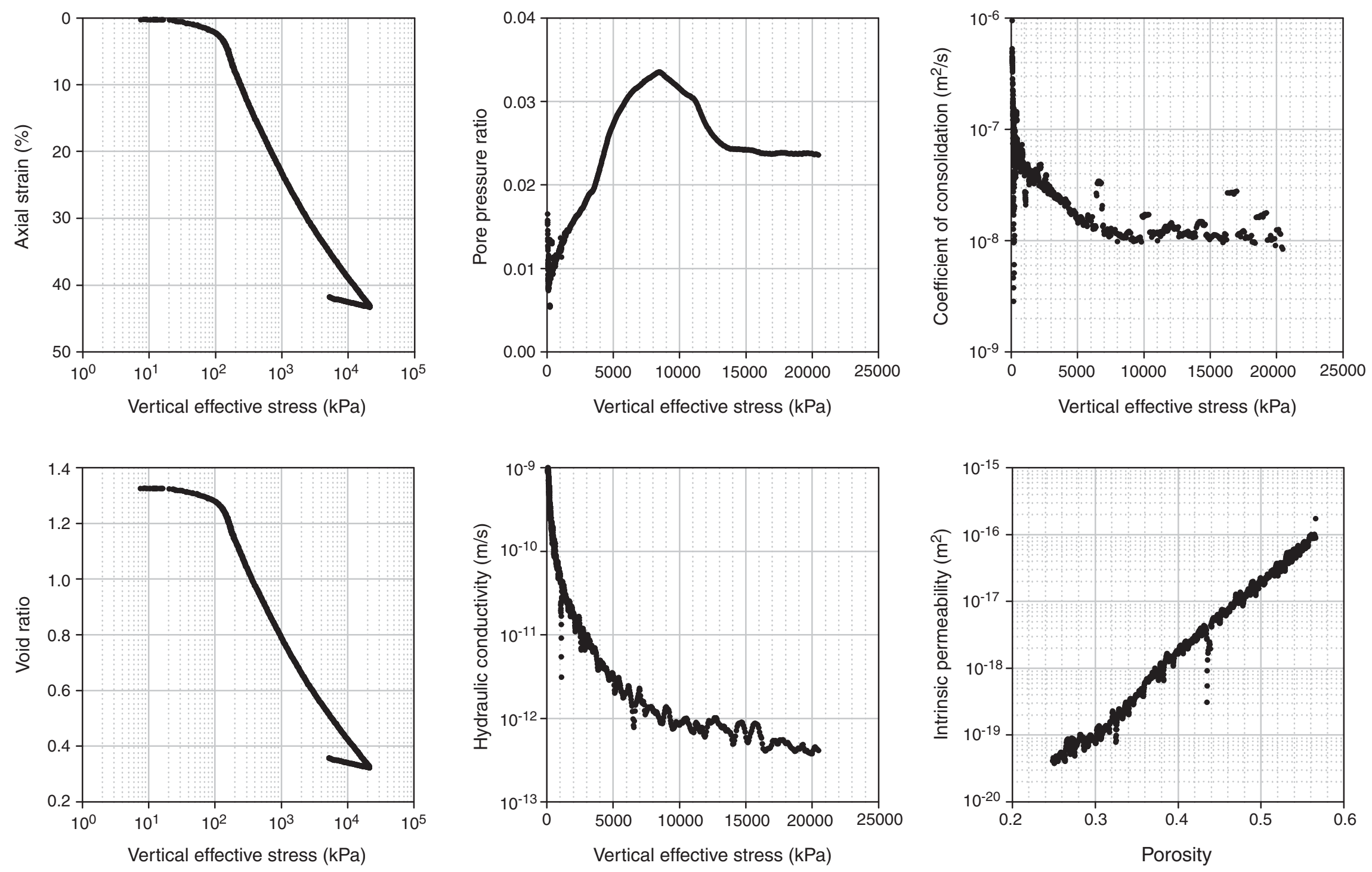
Figure F10. Experimental consolidation results for the sample with 41\% clay-size particles (64\% Nankai silty claystone and 36\% silica, CRS094). Consolidation data are in CRS in "Supplementary material."
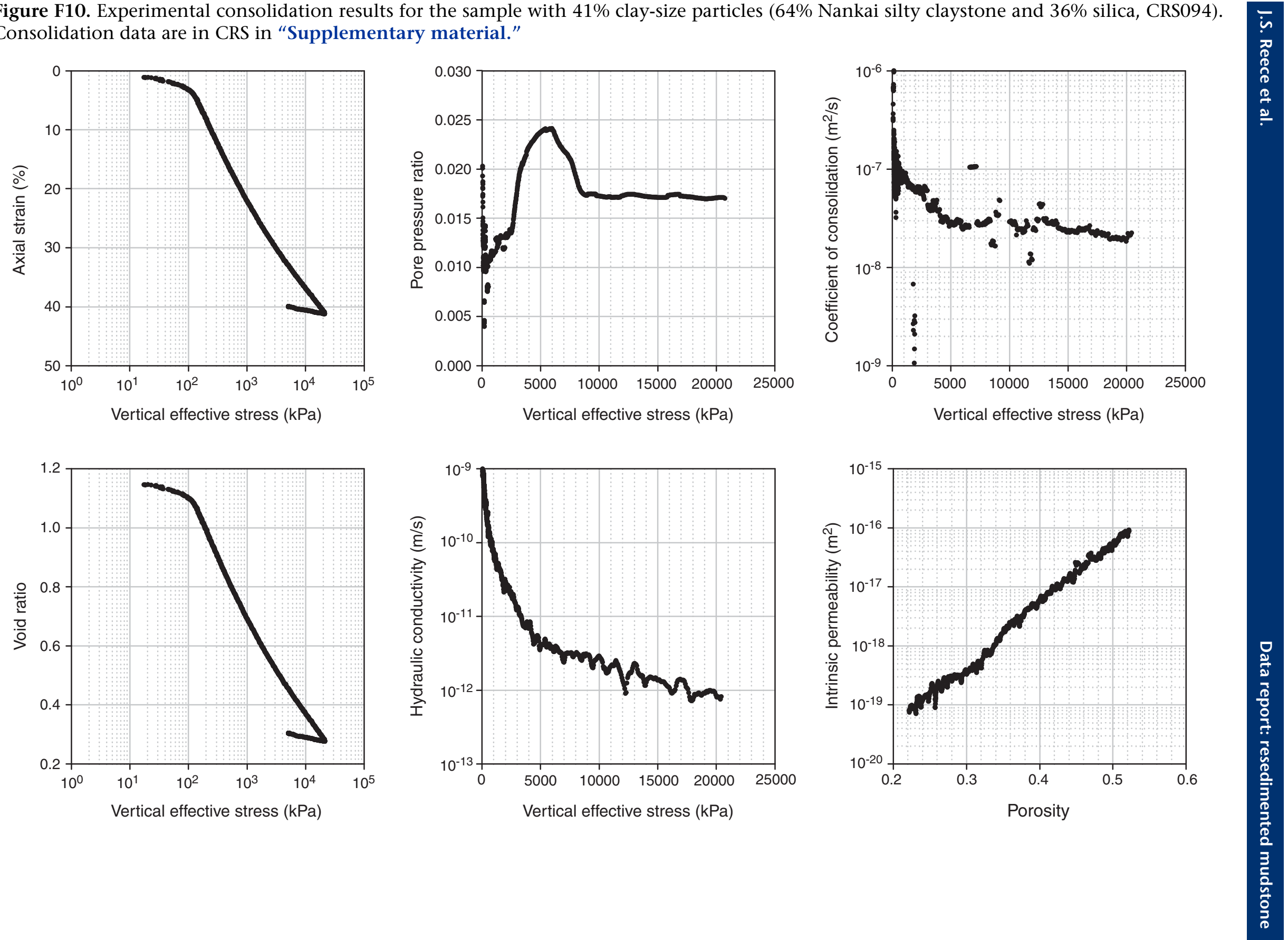
Figure F11. Experimental consolidation results for the sample with 36\% clay-size particles (52\% Nankai silty claystone and $48 \%$ silica, CRS089). Consolidation data are in CRS in "Supplementary material."
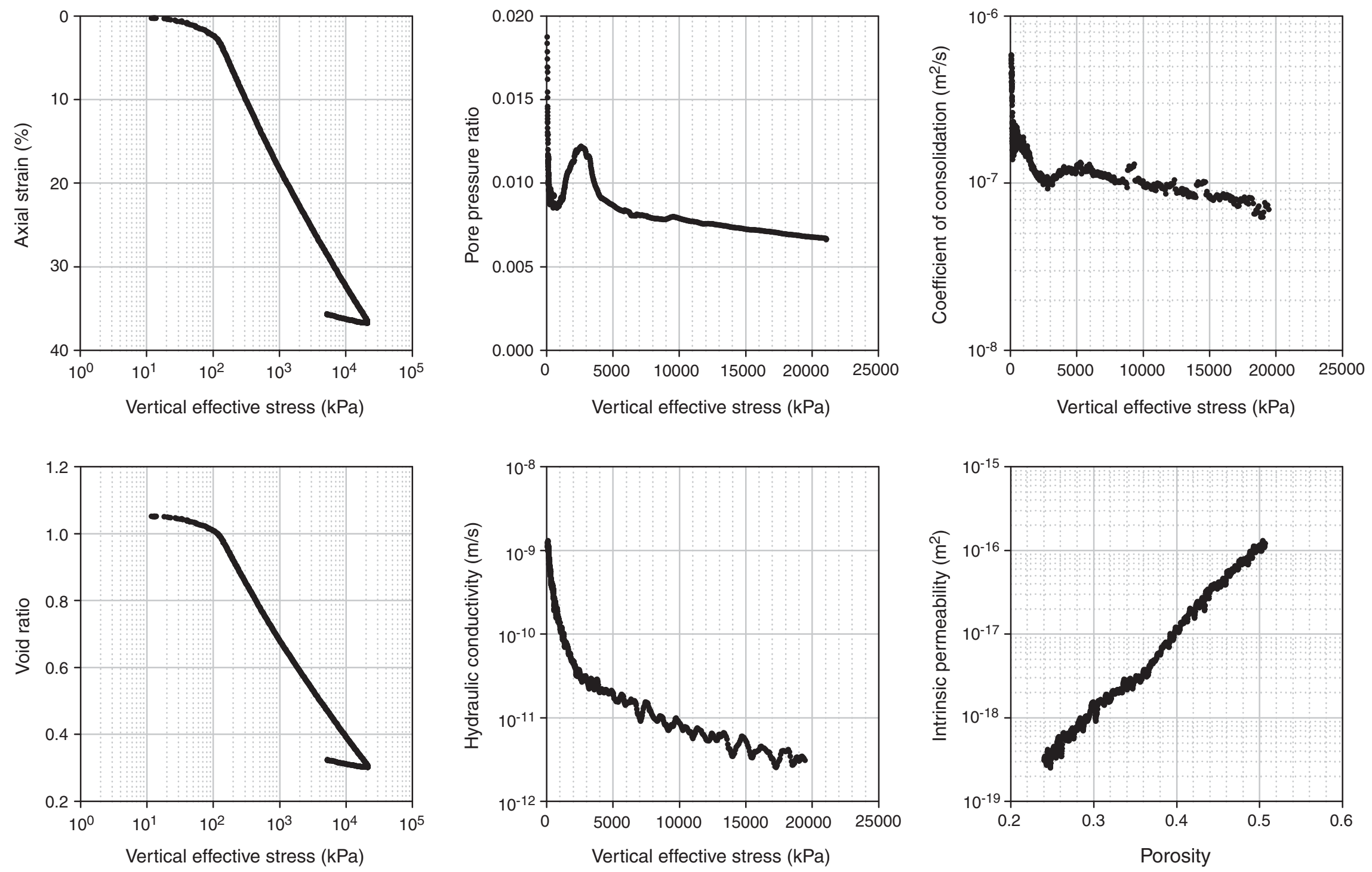
Figure F12. Experimental consolidation results for the sample with 32\% clay-size particles (40\% Nankai silty claystone and $60 \%$ silica, CRS088). Consolidation data are in CRS in "Supplementary material."
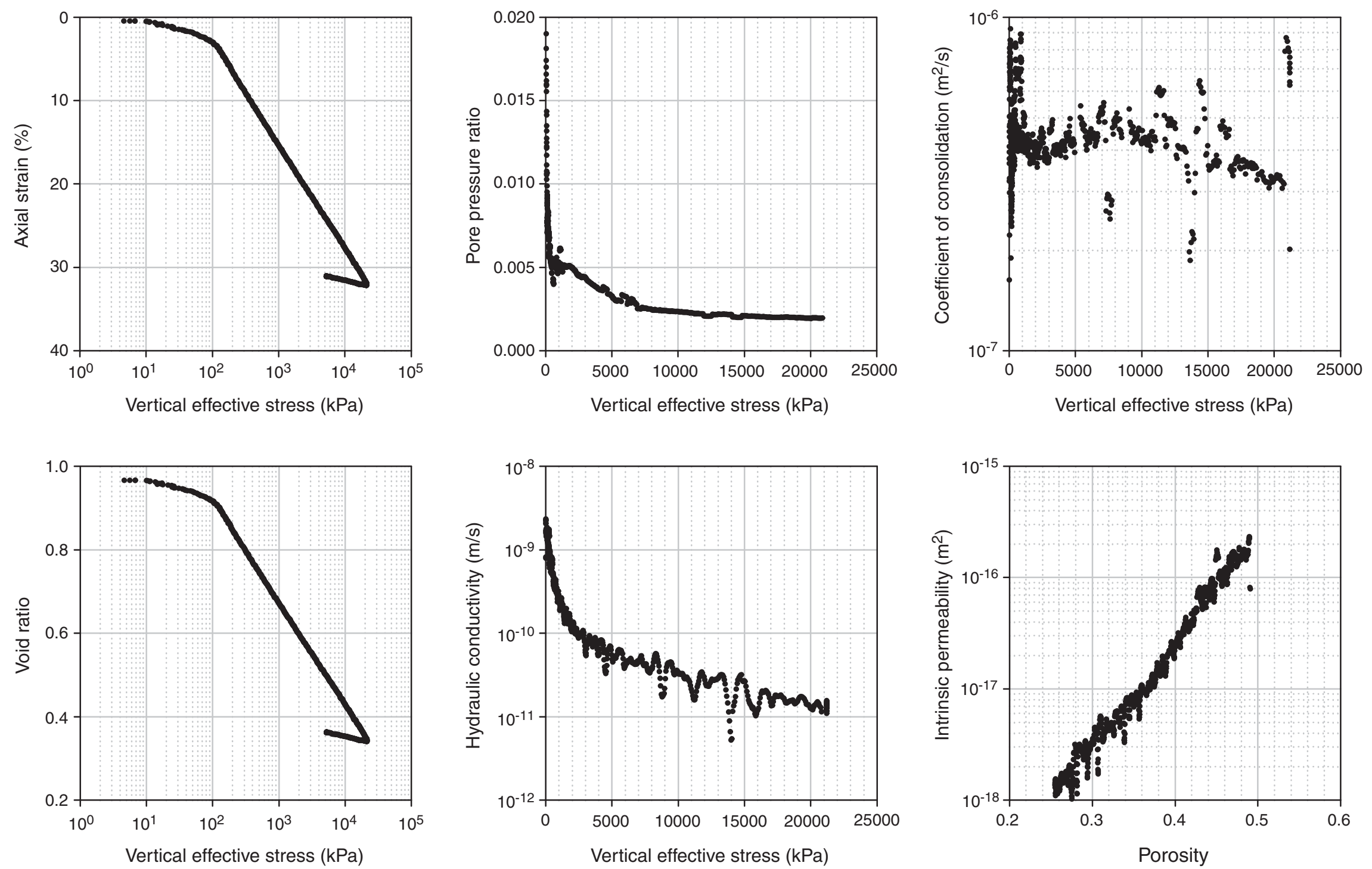
Figure F13. Scanning electron microscope images of Nankai silty claystone-silica mixtures after consolidation to a maximum vertical effective stress of $21 \mathrm{MPa}$. Images represent vertical cross section of samples (i.e., load was applied from the top of the images). Left column are BSE images. Right column are SE images. Magnification $=14,000 \times$. Additional BSE and SE images are in SEM in "Supplementary material." A, B. Nankai silty claystone (56\% clay). C, D. $50 \%$ clay. (Continued on next two pages.)
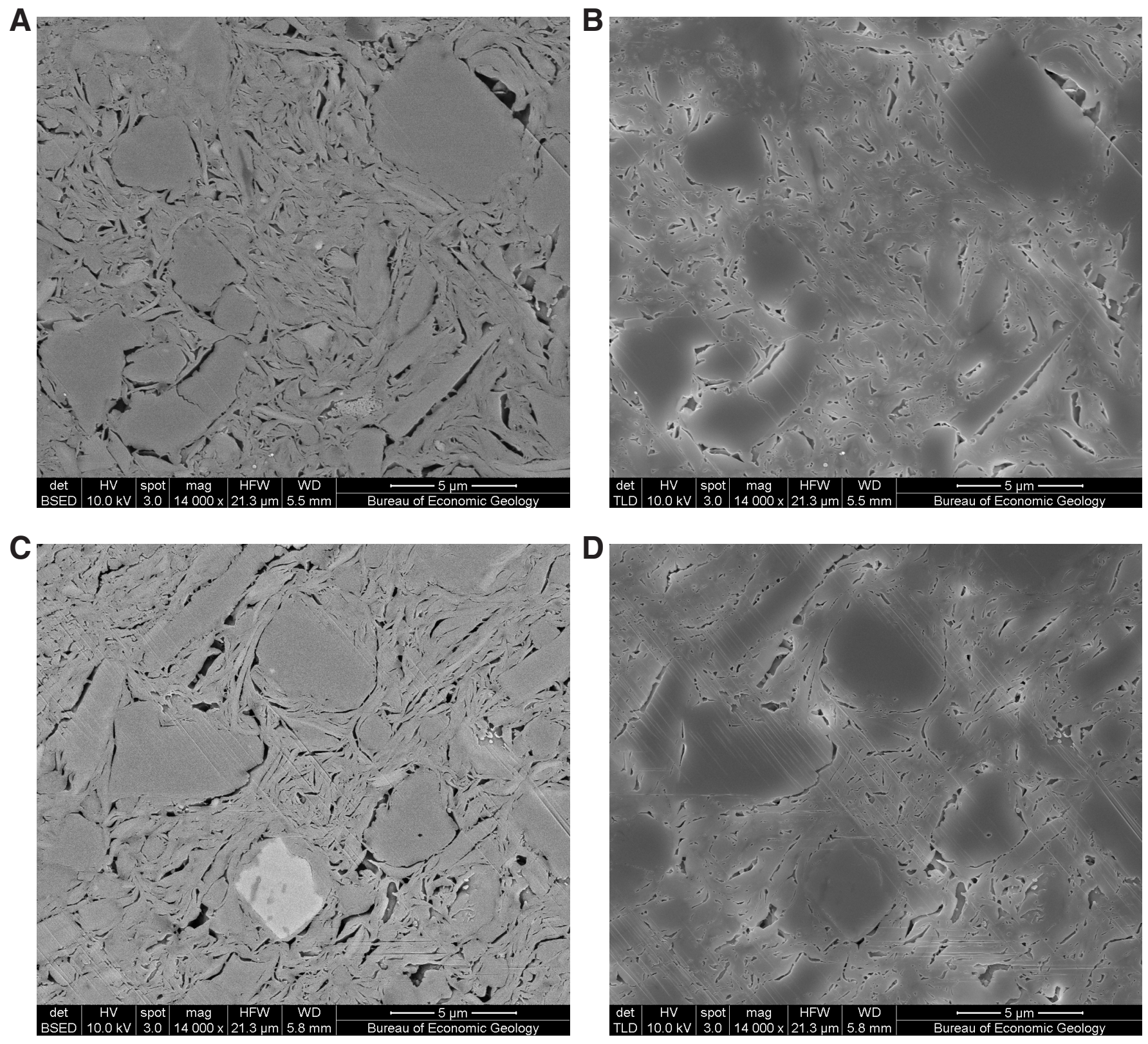
Figure F13 (continued). E, F. 48\% clay. G, H. 41\% clay. (Continued on next page.)

Figure F13 (continued). I, J. 36\% clay. K, L. 32\% clay.
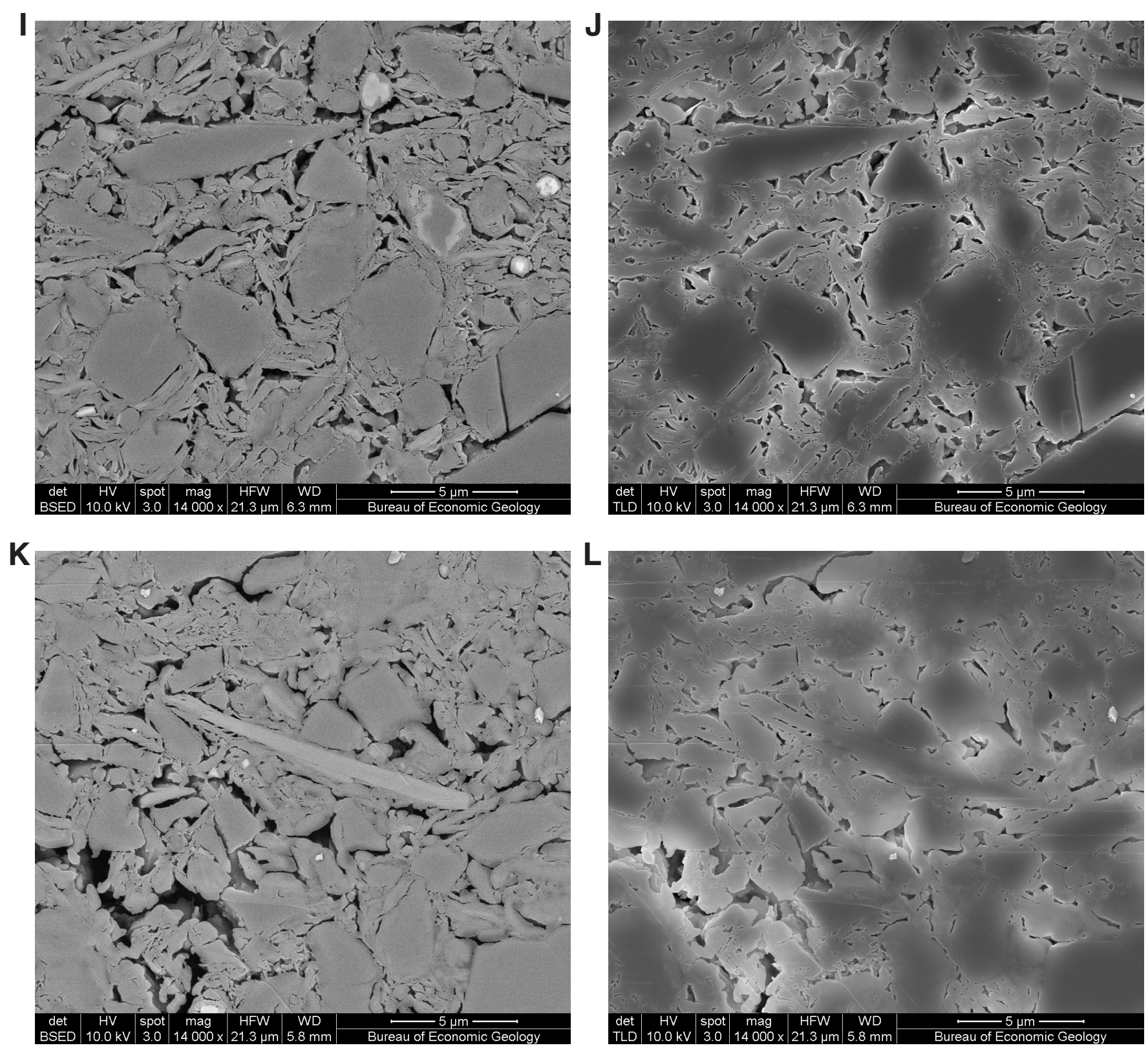
Table T1. Sample list, Site C0011.

\begin{tabular}{rlclll}
\hline $\begin{array}{c}\text { Bag } \\
\text { number }\end{array}$ & Core & $\begin{array}{c}\text { Core depth } \\
(\mathrm{mbsf})\end{array}$ & $\begin{array}{c}\text { Lith. } \\
\text { unit }\end{array}$ & \multicolumn{1}{c}{ Facies } & Mass (kg) \\
\hline \multicolumn{7}{c}{$\begin{array}{c}\text { 322-C0011B- } \\
1\end{array}$} & 31R-39R & $586.5-671.0$ & III & Hemipelagic & 3.0 \\
2 & $31 \mathrm{R}-39 \mathrm{R}$ & $586.5-671.0$ & III & Hemipelagic & 2.6 \\
3 & 30R & $580.4-584.4$ & III & Hemipelagic & 4.0 \\
4 & 30R & $580.4-584.4$ & III & Hemipelagic & 3.4 \\
5 & $51 \mathrm{R}-52 \mathrm{R}$ & $747.5-767.3$ & IV & Silty turbidite & 1.4 \\
6 & $43 \mathrm{R}$ & $685.0-689.0$ & IV & Silty turbidite & 0.7 \\
7 & $44 \mathrm{R}$ & $689.0-697.7$ & IV & Silty turbidite & 3.4 \\
8 & $40 \mathrm{R}-43 \mathrm{R}$ & $672.0-689.0$ & III, IV & Hemipelagic, silty turbidite & 1.3 \\
9 & $53 \mathrm{R}$ & $766.5-770.2$ & IV & Silty turbidite & 0.9 \\
10 & $54 \mathrm{R}-58 \mathrm{R}$ & $770.2-865.9$ & IV & Silty turbidite & 4.2 \\
\hline
\end{tabular}


Table T2. Mineralogy of Nankai silty claystone, Site C0011.

\begin{tabular}{|c|c|c|c|c|c|c|c|c|c|c|c|c|c|c|c|c|}
\hline \multicolumn{12}{|c|}{ Mineralogy of whole rock (wt\%) } & \multicolumn{5}{|c|}{$\begin{array}{c}\text { Mineralogy of clay minerals in clay-size fraction }(<2 \mu \mathrm{m}) \\
\text { (relative wt } \%)\end{array}$} \\
\hline Quartz & Plagioclase & K-feldspar & Calcite & Pyrite & Halite & Muscovite & Illite & Smectite & Kaolinite & Chlorite & Total & Chlorite & Kaolinite & Illite & Smectite & I/S expandability \\
\hline $24 \pm 3.0$ & $11 \pm 2.3$ & $5 \pm 1.7$ & $1 \pm 1.1$ & $1 \pm 1.0$ & $0 \pm 0.7$ & $3 \pm 1.4$ & $6 \pm 1.9$ & $45 \pm 3.8$ & $1 \pm 1.1$ & $4 \pm 1.6$ & 101 & 3 & 1 & 11 & 85 & 80 \\
\hline
\end{tabular}

I/S = illite/smectite

Table T3. Consolidation properties, Site C0011.

\begin{tabular}{|c|c|c|c|c|c|c|c|c|c|c|c|c|c|c|}
\hline \multirow[b]{2}{*}{ CRS } & \multirow{2}{*}{$\begin{array}{l}\text { Nankai silty } \\
\text { claystone } \\
(\%)\end{array}$} & \multirow[b]{2}{*}{$\begin{array}{l}\text { Silt } \\
(\%)\end{array}$} & \multicolumn{4}{|c|}{ Specimen data } & \multirow{2}{*}{$\begin{array}{c}\text { Test conditions } \\
d \varepsilon / d t \\
(\% / \mathrm{h})\end{array}$} & \multicolumn{7}{|c|}{ Consolidation properties } \\
\hline & & & $\begin{array}{l}w_{\mathrm{n}} \\
(\%)\end{array}$ & $\begin{array}{c}S_{i} \\
(\%)\end{array}$ & $e_{\mathrm{i}}$ & $G_{s}$ & & $\begin{array}{c}C_{c} \\
(0.2-1 \mathrm{MPa})\end{array}$ & $\begin{array}{c}C_{c} \\
(5-20 \mathrm{MPa})\end{array}$ & $\begin{array}{c}\mathrm{C}_{\mathrm{e}} \\
(5-20 \mathrm{MPa})\end{array}$ & $\begin{array}{l}\sigma_{p c}^{\prime} \\
(\mathrm{kPa})\end{array}$ & $\underset{\left(\mathrm{m}^{2}\right)}{\gamma}$ & $\log \left(k_{0}\right)\left(m^{2}\right)$ & $C_{v}\left(m^{2} / \mathrm{s}\right)$ \\
\hline CRS090 & 100 & 0 & 56.64 & 93.1 & 1.63 & 2.680 & 0.2 & 0.64 & 0.36 & 0.056 & 100 & 11.1 & -22.9 & $6.1 \mathrm{E}-9$ \\
\hline CRS091 & 88 & 12 & 54.09 & 93.0 & 1.56 & 2.676 & 0.35 & 0.56 & 0.32 & 0.053 & 100 & 11.6 & -22.8 & $5.6 \mathrm{E}-9$ \\
\hline CRS093 & 76 & 24 & 47.97 & 93.8 & 1.37 & 2.673 & 0.5 & 0.50 & 0.31 & 0.040 & 100 & 11.2 & -22.3 & $1.0 \mathrm{E}-8$ \\
\hline CRS094 & 64 & 36 & 42.50 & 94.3 & 1.20 & 2.669 & 0.7 & 0.43 & 0.29 & 0.036 & 100 & 10.5 & -21.5 & $2.0 \mathrm{E}-8$ \\
\hline CRS089 & 52 & 48 & 38.06 & 96.15 & 1.06 & 2.666 & 0.9 & 0.34 & 0.27 & 0.030 & 100 & 9.9 & -21.0 & $6.9 \mathrm{E}-8^{*}$ \\
\hline CRS088 & 40 & 60 & 34.76 & 94.90 & 0.98 & 2.662 & 1.05 & 0.26 & 0.24 & 0.017 & 100 & 9.8 & -20.5 & $3.2 \mathrm{E}-7^{*}$ \\
\hline
\end{tabular}

${ }^{*}=C_{v}$ determined at maximum vertical effective stress due to curvature of plot. CRS $=$ constant rate of strain consolidation test number. $w_{n}=$ water content measured on specimen; $e_{i}=$ initial

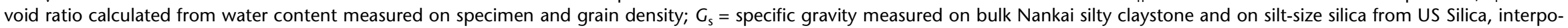

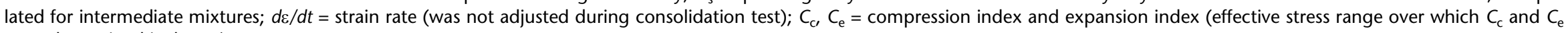
were determined is shown). 
Table T4. Nomenclature.

\begin{tabular}{|c|c|c|c|}
\hline Variable & Definition & Dimension & Unit \\
\hline$C_{c}$ & Compression index & Dimensionless & - \\
\hline$C_{e}$ & Expansion index & Dimensionless & - \\
\hline$C_{v}$ & Coefficient of consolidation & $\mathrm{L}^{2} / \mathrm{T}$ & $\mathrm{m}^{2} / \mathrm{s}$ \\
\hline$d \varepsilon / d t$ & Strain rate & $1 / \mathrm{T}$ & $1 / \mathrm{s}$ \\
\hline$e$ & Void ratio & Dimensionless & - \\
\hline$e_{\mathrm{i}}$ & Initial void ratio & Dimensionless & - \\
\hline $\mathrm{G}_{\mathrm{s}}$ & Specific gravity & Dimensionless & - \\
\hline$H$ & Specimen height & $\mathrm{L}$ & $\mathrm{cm}$ \\
\hline $\mathrm{H}_{0}$ & Initial specimen height & $\mathrm{L}$ & $\mathrm{cm}$ \\
\hline$k$ & Vertical intrinsic permeability & $\mathrm{L}^{2}$ & $\mathrm{~m}^{2}$ \\
\hline$k_{0}$ & Intercept of log-linear relationship between permeability and porosity & $\mathrm{L}^{2}$ & $\mathrm{~m}^{2}$ \\
\hline K & Hydraulic conductivity & $\mathrm{L} / \mathrm{T}$ & $\mathrm{m} / \mathrm{s}$ \\
\hline LL & Liquid limit & Dimensionless & $\%$ \\
\hline$m_{v}$ & Coefficient of volume compressibility & $\mathrm{LT}^{2} / \mathrm{M}$ & $1 / \mathrm{kPa}$ \\
\hline$n$ & Porosity & Dimensionless & - \\
\hline OCR & Overconsolidation ratio & Dimensionless & - \\
\hline $\mathrm{PI}$ & Plasticity index & Dimensionless & $\%$ \\
\hline PL & Plastic limit & Dimensionless & $\%$ \\
\hline$S_{i}$ & Initial saturation & Dimensionless & $\%$ \\
\hline$u$ & Base pressure/pore pressure & $\mathrm{M} / \mathrm{T}^{2} \mathrm{~L}$ & $\mathrm{kPa}$ \\
\hline$u_{c}$ & Backpressure/cell pressure & $\mathrm{M} / \mathrm{T}^{2} \mathrm{~L}$ & $\mathrm{kPa}$ \\
\hline$w_{n}$ & Specimen water content & Dimensionless & $\%$ \\
\hline$\Delta H$ & Change in height/deformation & L & $\mathrm{cm}$ \\
\hline$\Delta u$ & Excess pore pressure & $\mathrm{M} / \mathrm{T}^{2} \mathrm{~L}$ & $\mathrm{kPa}$ \\
\hline$\varepsilon$ & Strain & Dimensionless & $\%$ \\
\hline$\gamma$ & Slope of log-linear relationship between permeability and porosity & Dimensionless & - \\
\hline$\gamma_{w}$ & Unit weight of water & $M / T^{2} L^{2}$ & $\mathrm{~Pa} / \mathrm{m}$ \\
\hline$\mu_{\mathrm{w}}$ & Dynamic viscosity of water & $\mathrm{M} / \mathrm{TL}$ & Pa.s \\
\hline$\rho_{\mathrm{w}}$ & Density of water & $M / L^{3}$ & $\mathrm{~kg} / \mathrm{m}^{3}$ \\
\hline$\sigma_{\mathrm{v}}$ & Total axial stress & $\mathrm{M} / \mathrm{T}^{2} \mathrm{~L}$ & $\mathrm{kPa}$ \\
\hline$\sigma_{p c}^{\prime}$ & Preconsolidation stress & $\mathrm{M} / \mathrm{T}^{2} \mathrm{~L}$ & $\mathrm{kPa}$ \\
\hline$\sigma_{y}^{\prime c}$ & Vertical effective stress & $\mathrm{M} / \mathrm{T}^{2} \mathrm{~L}$ & $\mathrm{kPa}$ \\
\hline
\end{tabular}

Table T5. Atterberg limits of Nankai silty claystone-silt mixtures, Site C0011.

\begin{tabular}{ccccccc}
\hline $\begin{array}{c}\text { Nankai silty } \\
\text { claystone } \\
(\%)\end{array}$ & $\begin{array}{c}\text { Silica } \\
(\%)\end{array}$ & CRS & $\begin{array}{c}\text { Clay } \\
\text { fraction }\end{array}$ & LL (\%) & PL (\%) & PI (\%) \\
\hline 100 & 0 & BULK & 0.56 & 68 & 29 & 39 \\
100 & 0 & RESED & 0.56 & 60 & 29 & 31 \\
88 & 12 & CRS091 & 0.50 & 54 & 26 & 28 \\
76 & 24 & CRS093 & 0.48 & 51 & 22 & 29 \\
64 & 36 & CRS094 & 0.41 & 45 & 20 & 25 \\
52 & 48 & CRS089 & 0.36 & 40 & 20 & 20 \\
40 & 60 & CRS088 & 0.32 & 35 & 19 & 16 \\
\hline
\end{tabular}

Silica = silt-size silica (US MIN U SIL 40 purchased from US Silica). CRS = constant rate of strain consolidation test number: BULK $=$ Atterberg limits were performed on bulk, air-dried material before resedimentation and CRS testing; RESED = Atterberg limits were performed on additional, oven-dried resedimentation sample but from the same batch because of lack of material after CRS testing. Clay fraction = clay fraction by mass, $\mathrm{LL}=$ liquid limit, $\mathrm{PL}=$ plastic limit, $\mathrm{PI}=$ plasticity index. 
Table T6. Particle size distributions in mass-percent of Nankai silty claystone-silt mixtures, Site C0011.

\begin{tabular}{ccccccc}
\hline $\begin{array}{c}\text { Nankai silty } \\
\text { claystone } \\
(\%)\end{array}$ & $\begin{array}{c}\text { Silica } \\
(\%)\end{array}$ & CRS & PSD & Sand & Silt & Clay \\
\cline { 5 - 7 } & & & & & \multicolumn{3}{c}{ Particle size (\%) } \\
\hline 100 & 0 & CRS090 & PSD147 & 0 & 44 & 56 \\
88 & 12 & CRS091 & PSD148 & 0 & 50 & 50 \\
76 & 24 & CRS093 & PSD149 & 0 & 52 & 48 \\
64 & 36 & CRS094 & PSD150 & 0 & 59 & 41 \\
52 & 48 & CRS089 & PSD146 & 0 & 64 & 36 \\
40 & 60 & CRS088 & PSD145 & 0 & 68 & 32 \\
\hline
\end{tabular}

Sand/silt boundary is defined at $62.5 \mu \mathrm{m}$ and silt/clay boundary is defined at $2 \mu \mathrm{m}$. Silica = silt-size silica (US MIN U SIL 40 purchased from US Silica). $C R S=$ constant rate of strain consolidation test number, PSD = particle size analysis test number.

Table T7. Resedimentation results for Nankai silty claystone-silt mixtures, Site C0011.

\begin{tabular}{|c|c|c|c|c|c|c|c|c|c|c|c|}
\hline \multirow{2}{*}{$\begin{array}{c}\text { Nankai silty } \\
\text { claystone } \\
(\%)\end{array}$} & \multirow[b]{2}{*}{$\begin{array}{l}\text { Silt } \\
(\%)\end{array}$} & \multirow[b]{2}{*}{ Resed } & \multirow[b]{2}{*}{$C_{c}$} & \multicolumn{8}{|c|}{ Void ratio, $e$} \\
\hline & & & & $\begin{array}{c}\text { at } 2.60 \\
\mathrm{kPa}\end{array}$ & $\begin{array}{c}\text { at } 5.22 \\
\mathrm{kPa}\end{array}$ & $\begin{array}{c}\text { at } 10.46 \\
\mathrm{kPa}\end{array}$ & $\begin{array}{c}\text { at } 20.95 \\
\mathrm{kPa}\end{array}$ & $\begin{array}{c}\text { at } 41.92 \\
\mathrm{kPa}\end{array}$ & $\begin{array}{c}\text { at } 68.15 \\
\mathrm{kPa}\end{array}$ & $\begin{array}{c}\text { at } 99.62 \\
\mathrm{kPa}\end{array}$ & $\begin{array}{c}\text { at } 24.88 \\
\mathrm{kPa}\end{array}$ \\
\hline 100 & 0 & Resed062 T & 0.63 & 2.50 & 2.32 & 2.13 & 1.96 & 1.77 & 1.63 & 1.51 & 1.57 \\
\hline 88 & 12 & Resed051 B & 0.61 & 2.39 & 2.20 & 2.03 & 1.85 & 1.67 & 1.54 & 1.43 & 1.44 \\
\hline 76 & 24 & Resed052 T & 0.57 & 2.20 & 2.06 & 1.89 & 1.72 & 1.51 & 1.40 & 1.30 & 1.31 \\
\hline 64 & 36 & Resed054 T & 0.47 & 1.92 & 1.78 & 1.62 & 1.49 & 1.34 & 1.22 & 1.17 & 1.18 \\
\hline 52 & 48 & Resed056 T & 0.38 & 1.65 & 1.53 & 1.40 & 1.28 & 1.18 & 1.10 & 1.04 & 1.04 \\
\hline 40 & 60 & Resed059 T & 0.37 & 1.57 & 1.45 & 1.31 & 1.20 & 1.10 & 1.03 & 0.98 & 0.98 \\
\hline
\end{tabular}

Silica = silt-size silica (US MIN U SIL 40 purchased from US Silica). Resed = resedimentation test number (" $\mathrm{T}$ " and " $\mathrm{B}$ " refer to top and bottom specimen out of the two specimens per resedimentation batch). $C_{\mathrm{c}}=$ compression index, $e=$ void ratio at varying vertical effective stresses. 